\title{
Eye Discharge
}

National Cancer Institute

\section{Source}

National Cancer Institute. Eye Discharge. NCI Thesaurus. Code C35448.

Liquid exudate from the eye. 